\title{
United States - Definitive Safeguard Measures on Imports of Certain Steel Products (WT/DS259; WT/DS252; WT/DS248; WT/DS249; WT/DS251; WT/DS258; WT/DS254; WT/DS253: DSR 2003:VII, 3117)
}

\author{
GENE M. GROSSMAN \\ Princeton University \\ ALAN O. SYKES \\ University of Chicago
}

\section{Introduction}

Since the inception of the WTO, safeguard measures have regularly been the subject of dispute settlement proceedings. The latest in this chain of disputes concerns the definitive safeguard measures imposed by the United States on a wide range of steel products in 2002 .

The safeguards investigation of steel imports was initiated under the US law by the US International Trade Commission (USITC) at the request of the United States Trade Representative (USTR) in June, 2001. The request covered four broad categories of steel products, which were divided into 33 categories by the USITC for purposes of data collection. Ultimately, the USITC defined 27 separate "industries" producing steel products within the scope of the investigation. For each of these industries, the USITC proceeded to determine whether imports had increased, and if so, whether increased imports were a substantial cause of serious injury or threat of injury. This analysis resulted in negative determinations for 15 industries, 
affirmative determinations for eight industries, and "divided" determinations (a 3-3 vote) for four industries. ${ }^{1}$

Under the US law, a negative determination by the USITC precludes any action by the President to impose a safeguard measure. Affirmative determinations and divided determinations are forwarded to the President for consideration of possible relief, along with remedial recommendations that the President is not bound to follow. As to some products, the USITC has recommended that imports from nations with which the United States has preferential trading arrangements including Canada, Mexico, Israel, and Jordan - be exempted from any safeguard measures.

After the conclusion of an inter-agency review process, the President instituted ten distinct safeguard "measures" covering various steel products, which generally excluded imports from preferential trading partners. Eight WTO members (including the European Community) challenged the measures pursuant to the WTO dispute resolution process, and the proceedings were consolidated before a single Panel. The Panel ruled against the United States on all of the challenged measures, on multiple grounds. The Appellate Body affirmed the ruling in considerable part, leading to the eventual dismantling of the measures in December, 2003.

The issues before the Panel and the Appellate Body were by and large familiar ones, and their opinions broke little new ground. The Panel decision is by far the more interesting of the two, but in the end we view both opinions as simply the latest in a long line of unsatisfactory WTO decisions in the safeguards area. Our critique in this regard draws heavily on our prior work, along with the work of other American Law Institute (ALI) reporters. See Horn and Mavroidis (2003); Sykes (2003, 2004); Grossman and Mavroidis (2005).

Section 2 lays out some of the key legal issues in safeguards jurisprudence, and describes the state of the law prior to the steel dispute. Section 3 then considers the issues in the steel case, notes some interesting features of the Panel report, and shows how the Appellate Body decision added little to what had come before it. Section 4 offers some concluding thoughts about the future of safeguard measures in the WTO system and the need for coherent reforms.

${ }^{1}$ USITC, Certain Steel Products, Inv. No. TA-201-73, (USITC Pub. No. 3479, December, 2001), Vol. I (hereafter USITC Report). 


\section{Legal, historical, and economic background}

The legal basis for safeguards in the General Agreement on Tarriffs and Trade (GATT) system originally was found in Art. XIX, which became outmoded with the passage of time in a way that created serious confusion regarding the legal prerequisites for the use of safeguards. With the advent of the WTO, a new Safeguards Agreement elaborated additional legal constraints on the use of safeguards, but failed to resolve many of the central puzzles that had arisen under Art. XIX. Appellate Body decisions since the inception of the WTO have only made matters worse, to the point that the legal requirements for the use of safeguards are largely incoherent, and no nation can employ them without the near certainty of defeat in the dispute resolution process, should they be challenged. This section briefly reviews Art. XIX, the evolution of national practice under GATT, and the legal developments since the adoption of the Safeguards Agreement and prior to the steel decision.

\subsection{Article XIX and its interpretive puzzles}

GATT Art. XIX provides in paragraph (1):

If, as a result of unforeseen developments and of the effect of the obligations incurred by a contracting party under this Agreement, including tariff concessions, any product is being imported into the territory of that contracting party in such increased quantities and under such conditions as to cause or threaten serious injury to domestic producers in that territory of like or directly competitive products, the contracting party shall be free, in respect of such product, and to the extent and for such time as may be necessary to prevent or remedy such injury, to suspend the obligation in whole or in part or to withdraw or modify the concession.

\subsubsection{Unforeseen developments}

The first clause of Art. XIX provides that safeguard measures are permissible only following "unforeseen developments" associated with "the obligations incurred by a contracting party." What constitutes an "unforeseen development?" Unforeseen by whom, at what point in time? How does one determine the "effect of the obligations incurred?"

These questions had a natural answer at the outset of the GATT system. The original GATT negotiations concluded in 1947, with the expectation that GATT would be supplanted within a few years by 
a new institution to be called the International Trade Organization (which, of course, never came into being because of a shift in the political winds). The first clause of Art. XIX has a natural interpretation in the context of a trade agreement that was expected to be short-lived. The negotiators had made a number of trade concessions to each other in 1947, and Art. XIX provided for their suspension in the event that those concessions had an unforeseen, adverse impact on importcompeting industries due to a surge in import competition. To the questions posed above, therefore, one might answer that an "unforeseen development" was some development that caused the increase in imports following a trade concession under the original GATT to be greater than reasonably expected. It had to be unforeseen by the GATT negotiators, at the time of the 1947 negotiations. And the import surge had to result from one of the original GATT trade concessions, in the sense that it would not have happened but for some such concession.

But how does one interpret the requirements of Art. XIX(1), first clause, in an agreement that remains in force after many years? Consider an import surge 30 or 40 years after the agreement was drafted. What would it mean to say that such a surge resulted from the "obligations incurred," particularly if those obligations were incurred decades earlier? Could any such surge have been "foreseen" given the passage of so much time? By whom and when? And how are the answers affected by the fact that GATT negotiations are ongoing, with new negotiating "rounds" every decade or so? The requirements of the first clause no longer have a straightforward interpretation in an agreement that lasts for decades rather than a few years, and that is characterized by an ever-changing set of commitments.

For these reasons, GATT practice evolved over time toward ignoring the requirements of the first clause in $\operatorname{Art}$. $\operatorname{XIX}(1){ }^{2}$ National laws to authorize safeguard measures soon made no mention of them. Section 201 of the US Trade Act of 1974, for example, simply requires the USITC to determine "whether an article is being imported into the United States in such increased quantities as to be a substantial cause ${ }^{3}$ of serious injury, or the threat thereof." 4 There is no requirement that developments be "unforeseen" or that they result from earlier

${ }^{2}$ See McGovern (1986, p. 291).

3 A "substantial cause" is a "cause that it is important and not less than any other cause." 19 U.S.C. $\S 2252(\mathrm{~b})(1)(\mathrm{B})$.

419 U.S.C. $\S 2252(\mathrm{~b})(1)(\mathrm{A})$. 
trade concessions. At this writing, this statute remains the basis for safeguard measures under the US law.

Such a development is an understandable consequence of the difficulties in giving content to the first clause of Art. XIX in a long-lived agreement. But as shall become immediately apparent, the absence of this "anchor" for the remainder of Art. XIX(1) creates other problems.

\subsubsection{Serious injury and causation}

Under Art. XIX, it is not enough that an unforeseen import surge results from a trade concession. The import surge must go on to cause or threaten "serious injury." This phrasing raises other obvious interpretive issues - what is "serious injury?" How does one determine whether the "cause" of such injury (or threat thereof) is "increased quantities" of imports?

On the first question, the text appears deliberately vague. The drafters might have made reference to specifics in this regard - lost profits, unemployment, bankruptcies, and the like - but chose to leave the term undefined. Perhaps the best inference is that they did not want to constrain the concept unduly by attempting a definition, and that they would allow a variety of factors into the analysis.

On the question of causation, the logic was nevertheless fairly clear. The unforeseen import surge, resulting from the trade concession, had to be responsible for serious injury. Put differently, the serious injury had to be "caused" by the trade concession, via its effect on the level of import competition, in the usual but for sense of the term "cause." Within this framework, the "exogenous" variable is the trade concession, and the "increased quantities" of imports were those resulting from that concession. Likewise, the level of imports in the absence of the trade concession serves as the baseline against which to measure the "increase."

But now imagine reading out the first clause of paragraph one, as GATT members began to do many years ago. Then, one must simply have "such increased quantities [of imports] ... as to cause or threaten serious injury," as is required, for example, by the US law. The baseline for the "increase," import levels prior to a recent trade concession, is no longer available. Further, the only apparent candidate for an exogenous variable is the "increased quantities" of imports, as there is no longer any background event from which these "increased quantities" result. 
Two considerable problems arise as a result. First, how does one now determine whether there are "increased quantities" of imports at all - against what baseline is the increase to be measured?

Second, and more fundamental, how can one treat increased quantities of imports as an exogenous or "causal" variable? Elementary economics suggests that the forces of supply and demand will determine the quantity of imports, just as they do prices and domestic production. If imports and domestic products are perfect substitutes, for example, then the quantity of imports will equal the difference between domestic demand and domestic supply at the equilibrium price. That price, in turn, will be determined by the intersection between the domestic demand curve and the total supply curve, comprised of the sum of domestic supply and import supply. The exogenous factors in the economic framework are the determinants of domestic supply, domestic demand, and import supply. Domestic demand is affected by such things as domestic consumer tastes and incomes, domestic supply by the domestic costs of inputs into production and the state of available production technology, and import supply by the parallel factors that affect supply and demand in other countries. The quantity of imports is then a result of the interaction of these forces; it is not a causal variable at all.

Likewise, changes in the quantity of imports will be the result of changes in the determinants of domestic supply, demand, and the world price. Increased quantities of imports may result, for example, from a fall in the world price due to falling input costs abroad, to improved production technology abroad, or to weakening demand abroad. Increased quantities of imports can also result from an increase in domestic demand attributable, for example, to rising consumer incomes. Finally, increased quantities of imports can result from increasing costs of domestic production reflected in a leftward shift of the domestic supply schedule.

Against this backdrop, the question "did increased quantities of imports cause serious injury to a domestic industry?" is simply incoherent. Suppose, as an illustration, that the domestic industry suffers a decline due to rising costs. As domestic production falls at the world price, imports will increase to fill the rising gap between domestic demand and supply. Are "increased quantities" of imports the "cause" of this "injury?" Certainly not in the usual sense of the term "cause." By hypothesis, what has changed are the costs of domestic firms, and that change results in reduced domestic production and increased imports. 
Hence, once the first clause of Art. XIX(1) becomes a nullity, it is by no means clear how nations should operationalize their reliance on Art. XIX. There is no longer any natural baseline against which to measure "increased quantities," and there is no longer any intelligible exogenous variable to assess as the potential "cause" of serious injury.

\subsection{The Safeguards Agreement}

For reasons that would take us afield here, relating primarily to the proliferation of "gray-area" measures such as voluntary export restraints during the later years of GATT, the Uruguay Round negotiators concluded a new Agreement on Safeguards. Unfortunately, the Agreement did little to resolve the puzzles raised by Art. XIX(1).

On the basic preconditions for reliance on Art. XIX, the Agreement largely parrots the US law in stating that a "Member may apply a safeguard measure to a product only if that Member has determined ... that such product is being imported into its territory in such increased quantities, absolute or relative to domestic production, and under such conditions as to cause or threaten serious injury to the domestic industry that produces like or directly competitive products." 5 Like the US law, it omits any reference to "unforeseen developments" or the "effect of the obligations incurred."

The only guidance as to the meaning of "serious injury" and to the analysis of causation is provided by Art. 4 of the Agreement, which states in pertinent part:

1. For purposes of this Agreement:

(a) "serious injury" shall be understood to mean significant overall impairment in the position of a domestic industry;

(b) "threat of serious injury" shall be understood to mean serious injury that is clearly imminent ...

2. (a) In the investigation to determine whether increased imports have caused or are threatening to cause serious injury to a domestic industry ... the competent authorities shall evaluate all relevant factors of an objective and quantifiable nature having a bearing on the situation of that industry, in particular, the rate and amount of the increase in imports of the product concerned in absolute and relative terms, the share of the domestic market

${ }^{5}$ Id. Art. 2(1). 
taken by increased imports, changes in the level of sales, production, productivity, capacity utilization, profits and losses, and employment.

(b) The determination referred to in subparagraph (a) shall not be made unless this investigation demonstrates, on the basis of objective evidence, the existence of the causal link between increased imports of the product concerned and serious injury or threat thereof. When factors other than increased imports are causing injury to the domestic industry at the same time, such injury shall not be attributed to increased imports.

Plainly, this provision does not seriously address, let alone resolve, the conundrums presented by modern GATT practice under Art. XIX. It does not provide any guidance, for example, on what it means to say that increased imports are a causal variable, or any guidance on what is meant by "factors other than increased imports ... causing injury to the domestic industry at the same time." The concept of "serious injury" is left quite vague, and members must simply "evaluate" relevant factors. Further, although the Agreement nowhere refers to "unforeseen developments" and the "effect of the obligations incurred" as a predicate to safeguard measures, it does not specifically provide that Art. XIX(1), first clause, may henceforth be ignored.

Hence, fundamental questions regarding the legal prerequisites for safeguard measures remain unanswered by the WTO Agreement on Safeguards. These unresolved issues have found their way into WTO disputes.

\subsection{Safeguards in Appellate Body jurisprudence prior to the steel case}

\subsubsection{The Resurrection of unforeseen developments}

As indicated, GATT practice evolved toward ignoring the unforeseen developments requirement of Art. XIX, and the Safeguards Agreement says nothing about that requirement. But in its first important ruling in a safeguards dispute - Korea - Dairy ${ }^{6}$ - the Appellate Body overruled the dispute Panel's findings in the case to the effect that formal compliance with Art. XIX(1), first clause, was no longer required. The Appellate Body instead held that a treaty interpreter "must give meaning and effect to all the terms of the treaty. An interpreter is not free to adopt a reading that would result in reducing whole clauses

${ }^{6}$ Korea - Definitive Safeguard Measure on Imports of Certain Dairy Products, WT/DS98/AB/R (1999). 
or paragraphs of a treaty to redundancy or inutility." ${ }^{\prime 7}$ Article XIX and the Safeguards Agreement are to be read cumulatively it said, and the first clause of Art. XIX remained a binding obligation.

As for the proper interpretation of the obligation imposed by Art. XIX(1), first clause, the Appellate Body opined: "[I]t seems to us that the ordinary meaning of the phrase 'as a result of unforeseen developments' requires that the developments which led to a product being imported in such increased quantities and under such conditions as to cause or threaten to cause serious injury to domestic producers must have been 'unexpected.' With respect to the phrase 'of the effect of the obligations incurred by a Member under this Agreement, including tariff concessions,' we believe that this phrase simply means that it must be demonstrated, as a matter of fact, that the importing Member has incurred obligations under the GATT 1994, including tariff concessions." ${ }^{\prime 8}$ The Appellate Body went on to endorse the reasoning of the working party report in the old GATT Hatter's Fur case, ${ }^{9}$ which stated: “... 'unforeseen developments' should be interpreted to mean developments occurring after the negotiation of the relevant tariff concession which it would not be reasonable to expect that the negotiators of the country making the concession could and should have foreseen at the time when the concession was negotiated."10 This line of reasoning was repeated by the Appellate Body in Argentina - Footwear, ${ }^{11}$ which also overruled the dispute Panel in the case.

Thus, the Appellate Body has fully revived the first clause of Art. XIX, and has held in these and subsequent decisions that national authorities have failed to demonstrate their compliance with it. United States Lamb, ${ }^{12}$ in particular, holds that WTO members must demonstrate their compliance with the Art. XIX(1), first clause, prior to the time that a safeguards measure is undertaken. The USITC's failure to consider the matter in its Lamb investigation was "not surprising" given the absence of any reference to it in the governing US statute, but that was no defense for the United States under WTO law. ${ }^{13}$

One can certainly quarrel with the legal soundness of these decisions. Given the uniform practice of ignoring Art. XIX(1), first clause,

\footnotetext{
${ }^{7}$ Id. $\uparrow$ 80. ${ }^{8}$ Id. $\uparrow 84 . \quad{ }^{9}$ Sales No. GATT/1951-3 (Nov. 1951). ${ }^{10}$ Id. $\uparrow 89$.

11 Argentina - Safeguard Measures on Imports of Footwear, WT/DS121/AB/R (1999).

12 United States - Safeguard Measures on Imports of Fresh, Chilled or Frozen Lamb Meat from New Zealand and Australia, WT/DS178/AB/R (2001).

${ }^{13}$ Id. $\uparrow 73$.
} 
during the latter years of GATT, and its omission from the Safeguards Agreement, it is questionable whether the drafters of the Uruguay Round Agreements had any intention of reviving the obligation - had they wished to alter the established GATT practice in this respect, one might argue, they would have indicated so with clarity. The difficult interpretive issues that the clause raises in a long-lived agreement, which led to its irrelevance in GATT practice, might also have been noted as a basis for letting it remain dormant.

Having embraced the opposite view, the Appellate Body might have undertaken to explain coherently what Art. XIX(1), first clause, now requires. At what point in time must the events in question have been unforeseen - at the time of the last tariff concession? What if the last concession on the product in question was decades ago - could anything today have been foreseen? What if, over time, the product has been the subject of numerous tariff concessions - are expectations associated with the last concession the only relevant ones? Why or why not? How does one establish the expectations of trade negotiators as an evidentiary matter? What if there are many negotiators and their accounts of their expectations are incongruent? What if most of them are dead? This list of questions is assuredly incomplete.

With regard to the "effect of the obligations incurred," by contrast, the Appellate Body apparently offers a construction that enables this requirement to be trivially satisfied in every case - a member need simply show that it has incurred some obligations with respect to the product in question. It is hard to imagine how a dispute could arise without such an obligation, since a member with an unbound tariff could always raise it unilaterally without any need to rely on a safeguard measure. The Appellate Body evidently does not require members to demonstrate that "increased quantities" of imports are attributable directly to any recent trade concession. It suffices for them to argue that in the absence of a tariff binding, they would be able to raise tariffs to eliminate the import surge.

\subsubsection{Increased quantities}

As noted, Art. XIX originally contemplated that "increased quantities" of imports would be measured against baseline levels prior to 1947 GATT concessions. Having revived Art. XIX(1), first clause, therefore, one might perhaps have expected the Appellate Body to require a similar approach to establishing the baseline against which the existence 
of "increased quantities" is assessed, perhaps by looking to import levels prior to the most recent concession on the product in question. But it has not taken that approach.

In Argentina - Footwear, ${ }^{14}$ the Appellate Body considered a case in which Argentina had adopted the approach embraced some years earlier by the USITC - a five-year "rule of thumb" for establishing the import baseline. The dispute Panel in the case concluded that it is "reasonable to examine the trend in imports over a five-year historical period." 15 But the Appellate Body focused on language from the second clause of Art. XIX(1) and its counterpart in Art. 2.1 of the Safeguards Agreement: "any product [that] is being imported into the territory of that contracting party in such increased quantities and under such conditions as to cause or threaten to cause serious injury." The phrase "is being imported," according to the Appellate Body, "indicates that it is necessary for the competent authorities to examine recent imports, and not simply trends in imports during the past five years - or, for that matter, during any other period of several years." "In our view, the determination of whether the requirement of imports 'in such increased quantities' is met is not a merely mathematical or technical determination. In other words, it is not enough for an investigation to show simply that imports of the product this year were more than last year - or five years ago. Again, and it bears repeating, not just any increased quantities of imports will suffice. There must be 'such increased quantities' as to cause or threaten to cause serious injury to the domestic industry in order to fulfill this requirement for applying a safeguard measure. And this language in both Art. 2.1 of the Agreement on Safeguards and Art. XIX:1(a) of the GATT 1994, we believe, requires that the increase in imports must have been recent enough, sudden enough, sharp enough, and significant enough, both quantitatively and qualitatively, to cause or threaten to cause 'serious injury.' "'17

Thus, the Appellate Body insists that imports must have increased "recently." But how recently, and in what amount? The phrase "recent enough, sudden enough, sharp enough, and significant enough, both quantitatively and qualitatively, to cause or threaten to cause 'serious injury" " hardly provides useful guidance. The insistence on "not just any increase" but "such increased quantities" as to cause injury is equally unhelpful. And one must again confront the fundamental issue

14 Argentina - Safeguard Measures on Imports of Footwear, WT/DS121/AB/R (1999).

15 Id. 130. 16 Id. 130.17 Id. 131. 
that all of this verbiage avoids - what does it mean to say that increased quantities of imports "cause" injury when they are, as an economic matter, a result of a variety of possible developments? Far from lending badly needed clarification, the Appellate Body's treatment of the "increased quantities" requirement only adds to the confusion.

\subsubsection{Serious injury}

Like Art. XIX and the Safeguards Agreement, the Appellate Body has not attempted to define "serious injury" with any precision. Its focus has been primarily on the text of Art. 4.2, which simply provides: "the competent authorities shall evaluate all relevant factors of an objective and quantifiable nature having a bearing on the situation of that industry, in particular, the rate and amount of the increase in imports of the product concerned in absolute and relative terms, the share of the domestic market taken by increased imports, changes in the level of sales, production, productivity, capacity utilization, profits and losses, and employment." According to the Appellate Body, the text requires that all of the listed factors be "evaluated" in every case, and it has found safeguard measures wanting under the WTO law whenever a member has failed to discuss one or more of these factors in its official report on safeguard action. ${ }^{18}$ The Appellate Body has further held that the obligation to evaluate "all relevant factors" may extend to factors not raised by any of the parties to the safeguards investigation. ${ }^{19}$

Otherwise, the Appellate Body has simply insisted that serious injury represents "significant overall impairment" as stated in Art. 4.1 of the Safeguards Agreement. ${ }^{20}$ It characterizes this standard as "high" and

${ }^{18}$ See Argentina - Safeguard Measures on Imports of Footwear, WT/DS121/AB/R (1999), $\checkmark 121$.

19 See United States - Definitive Safeguard Measures on Imports of Wheat Gluten from the European Communities, WT/DS166/AB/R (2001), $\uparrow 55$.

20 To date, the Appellate Body has largely refrained from detailed commentary on the reasoning behind findings of "serious injury" by national authorities. The most notable exception is United States - Safeguard Measures on Imports of Fresh, Chilled or Frozen Lamb Meat from New Zealand and Australia, WT/DS178/AB/R (2001). The USITC had found lamb prices in the United States to be "depressed" even though they were generally higher than four or five years earlier. And it had found a threat of serious injury even though prices had risen toward the end of its period of investigation. The Appellate Body held these findings to be insufficient to support the USITC determination. Id. $\uparrow \uparrow 157-59$. 
"exacting.", It is not necessary that every "relevant factor" reflect industrial decline, however, for serious injury to be present - "a certain factor may not be declining, but the overall picture may nevertheless demonstrate 'significant overall impairment.' ",22

On the whole, therefore, the Appellate Body has provided relatively little guidance on the meaning of "serious injury," a situation that is perhaps understandable given the vagueness of the pertinent textual obligations. Beyond a requirement that all factors listed in the Safeguards Agreement be "evaluated" in each case, it remains unclear what conditions will support a finding of serious injury or threat, and what degree of deference on the matter will be afforded to national authorities.

\subsubsection{Causation}

The Appellate Body has addressed the causal relationship between increased quantities of imports and serious injury in several opinions prior to the steel case. None of them, however, provides clear answers to the conceptual difficulties identified in Section 1.

Argentina - Footwear briefly addresses the proper method for determining whether imports are the "cause" of injury. The dispute Panel in that case indicated that "if causation is present, an increase in imports normally should coincide with a decline in the relevant injury factors." 23 The Appellate Body agreed with the Panel that "in an analysis of causation, it is the relationship between the movements in imports (volume and market share) and the movements in injury factors that must be central to a causation analysis and determination.' "' The Appellate Body further noted that "with respect to a 'coincidence' between an increase in imports and a decline in the relevant injury factors, [] the Panel simply said that this should 'normally' occur if causation is present." 24

Hence, in its first important statement on the subject, the Appellate Body tips its hat to the notion that correlation and causation are not

21 United States - Safeguard Measures on Imports of Fresh, Chilled or Frozen Lamb Meat from New Zealand and Australia, WT/DS178/AB/R (2001), 124.

${ }^{22}$ Argentina - Safeguard Measures on Imports of Footwear, WT/DS121/AB/R (1999), $\uparrow 139$.

${ }^{23}$ Argentina - Safeguard Measures on Imports of Footwear, WT/DS121/AB/R (1999), $\uparrow 141$.

${ }^{24}$ Id. $\uparrow 144$. 
the same, but implies that they "normally" go hand in hand. One has no sense that the Appellate Body is aware of (or at least troubled by) the profound conceptual difficulty in confounding the two in a setting where the ostensible "causal" variable is in fact endogenous.

The other Appellate Body opinions on causal analysis focus principally on the so-called "non-attribution requirement" of Art. 4.2 of the Safeguards Agreement. It provides that safeguard measures may not be employed unless the "investigation demonstrates, on the basis of objective evidence, the existence of the causal link between increased imports of the product concerned and serious injury or threat thereof. When factors other than increased imports are causing injury to the domestic industry at the same time, such injury shall not be attributed to increased imports." One question raised by this language during the course of various disputes has been whether the harm "caused" by increased imports (again suspending the issue of what it means to treat increased imports as causal) must by itself suffice to cause serious injury, or must simply contribute to serious injury, perhaps along with other factors. To this ill-posed question, the Appellate Body has responded that "the Agreement on Safeguards does not require that increased imports be 'sufficient' to cause, or threaten to cause, serious injury. Nor does that Agreement require that increased imports 'alone' be capable of causing, or threatening to cause, serious injury." 25

Although increased imports need not account for all of the serious injury, the Appellate Body nevertheless underscores the importance of ensuring that injury caused by "factors other than increased imports" "not be attributed to increased imports." To make sense of these dual principles, one can only assume that the Appellate Body is concerned about situations in which increased imports have not made any causal contribution to serious injury, and where serious injury is nevertheless wrongly "attributed" to imports.

It has found fault with Members' "non-attribution analysis" on multiple occasions. In United States - Wheat Gluten, ${ }^{26}$ the volume of imports had risen $38 \%$ during the five-year period of investigation

${ }^{25}$ United States - Safeguard Measures on Imports of Fresh, Chilled or Frozen Lamb Meat from New Zealand and Australia, WT/DS178/AB/R (2001), -170. See also United States - Definitive Safeguard Measures on Imports of Wheat Gluten from the European Communities, WT/DS166/AB/R (2001), $\uparrow 70$.

${ }^{26}$ United States - Definitive Safeguard Measures on Imports of Wheat Gluten from the European Communities, WT/DS166/AB/R (2001). 
employed by the USITC. Over the same period, the US productive capacity had grown $68 \%$. Capacity utilization at US firms had fallen considerably along with profits, however, and the USITC had linked the decline in profitability to declining capacity utilization rates. ${ }^{27}$

One issue before the Appellate Body was whether the USITC had incorrectly "attributed" injury caused by the expansion of the US capacity to rising imports. On this question, the Appellate Body noted that, had the US capacity not risen over the period of investigation, its capacity utilization rate would have fallen only modestly even with the increased volume of imports. ${ }^{28}$ Further, had imports maintained their market share over the period of investigation, capacity utilization rates still would have fallen significantly due to the increased capacity brought on line. ${ }^{29}$ In the face of this evidence, the Appellate Body concluded that the USITC had not "adequately evaluated the complexities" and had not "ensured that injury attributable to other factors [was] not 'attributed' to imports." 30

The Wheat Gluten opinion is problematic in a number of respects. First, as with the other Appellate Body opinions on causation, it does nothing to help with the question of how to conceptualize imports as a causal variable. Second, taking seriously for a moment the notion that imports are "causal," it was undisputed in the case that they had risen substantially during the period of investigation, while the profitability of domestic producers had fallen. Given the Appellate Body's earlier pronouncements that a correlation of this sort is "normally" present when a causal connection exists, and that imports need not account for all serious injury, one wonders why this evidence was not enough. The logic of the Appellate Body opinion seems to suggest that the problems suffered by US producers were caused by two factors rising imports, and investment in new capacity that proved unnecessary. In the absence of either factor, US producers would have been considerably more profitable. Why, then, is it inappropriate to attribute at least part of the "serious injury" to imports?

Finally, and as the United States argued, much of the increase in capacity was put in place before imports began to increase. ${ }^{31}$ The sequence of events thus suggested that US producers had invested in new capacity in anticipation of growth opportunities, but that imports had increased to capture those growth opportunities and render

27 Id. $\uparrow \mid 81,84 . \quad{ }^{28}$ Id. $\uparrow 85 . \quad{ }^{29}$ Id. $\uparrow 86 . \quad{ }^{30}$ Id. $91 . \quad{ }^{31}$ Id. $\uparrow 87$. 
the new investment uneconomical. It could thus be argued that the unexpected surge in imports was the real "problem," and that investments in capacity were not a conceptually distinct cause of injury but rather a background predicate for the injury caused by imports. To this line of argument, the Appellate Body responded: "[T]he relevance of an 'other factor,' under Art. 4.2(b), depends on whether that 'other factor' was, or was not, 'causing injury' 'at the same time' as increased imports. Therefore, the possible relevance of the increases in capacity added during the period of investigation does not depend on the moment in time when the increases in capacity occurred, but on when the effects of those increases are felt, and whether they are 'causing injury' 'at the same time' as increased imports." ${ }^{\text {, }} 2$ This response simply begs the question as to why domestic investments in new capacity should be considered an "other factor" distinct from imports as a cause of injury, if indeed the anticipated recoupment of those investments was frustrated by an unexpected import surge. The USITC had treated capacity investments as an alternative cause of injury to be sure (and dismissed them as less important), and the Appellate Body simply seemed to accept it as an "other factor" without reflection.

The decision in United States - Lamb $b^{33}$ is similar in this last respect. The USITC had considered six factors other than the increased imports that might have contributed to serious injury: "the cessation of subsidy payments under the National Wool Act of 1954; competition from other meat products, such as beef, pork and poultry; increased input costs; overfeeding of lambs; concentration in the packing segment of the industry; and a failure to develop and maintain an effective marketing program for lamb meat." 34 The Appellate Body again seemed to accept these factors uncritically, and simply inquired whether the United States had done enough to ensure that injury caused by these factors was not "attributed" to imports. Once again it found the analysis of the USITC wanting, suggesting that it consisted of conclusory assertions without reasoned explanation. ${ }^{35}$ Along the way, the Appellate Body added: "We emphasize that the method and approach WTO Members choose to carry out the process of separating the effects of increased imports and the effects of the other causal factors

32 Id. 988.

33 United States - Safeguard Measures on Imports of Fresh, Chilled or Frozen Lamb Meat from New Zealand and Australia, WT/DS178/AB/R (2001).

34 Id. at $\uparrow 182$, n. $57 . \quad{ }^{35}$ Id. $\uparrow 185-86$. 
is not specified by the Agreement on Safeguards. What the Agreement requires is simply that the obligations in Art. 4.2 must be respected when a safeguard measure is applied." ${ }^{36}$ Evidently, Members can use any analytical method they wish that complies with Art. 4.2, yet the Appellate Body offers no counsel as to what the set of permissible methods might include.

Finally, in United States - Line Pipe, ${ }^{37}$ the USITC had considered the possibility that decreased oil and gas drilling was a more important cause of injury than increased imports, and had concluded to the contrary. Once again, however, its analysis was deemed insufficient the "cited parts of the USITC Report do not establish explicitly, with a reasoned and adequate explanation, that injury caused by factors other than the increased imports was not attributed to increased imports. The passage on page I-30 of the USITC Report highlighted by the United States is but a mere assertion that injury caused by other factors is not attributed to increased imports." 38

In sum, the Appellate Body decisions prior to the steel case, regarding the causal analysis required by the Safeguards Agreement, suggest the following principles: (a) correlation is typically the best evidence of causation; (b) the "other factors" considered by national authorities during the course of their investigations will be accepted uncritically without any reflection as to their logical relevance; and (c) the Appellate Body will not tell nations how to conduct their "non-attribution analysis," but will insist that it contain "reasoned and adequate explanation," which has so far been lacking in every case. In these decisions, the Appellate Body offers no theory as to how imports are to be viewed as causal, or as to how members should determine what constitutes a potential "other factor." It faults the lack of "adequate explanation" in the decisions of national authorities, yet its own explanation of the permissible role for safeguard measures could hardly be less instructive.

\section{The steel dispute}

The recent steel dispute raised all of the issues noted above, and others. The Panel decision hints at a partial resolution of the

\footnotetext{
36 Id. $\uparrow 181$.

37 United States - Definitive Safeguard Measures on Imports of Circular Welded Carbon Quality Line Pipe from Korea, WT/DS202/AB/R (2001).

38 Id. $\top 220$.
} 
"unforeseen developments" puzzle, but makes little progress on other fronts. The Appellate Body decision breaks no new ground at all, and holds the steel safeguards imposed by the United States to be illegal for predictable reasons in light of the prior cases.

\subsection{The panel decision}

The challenges to the US steel safeguard measures collectively attacked every aspect of their legal basis. The Panel exercised judicial economy to avoid addressing arguments regarding the definition of "industry" in the US investigation and the existence of serious injury. Its findings instead focused on four areas: the existence of "unforeseen developments" as a predicate for safeguards; the question of whether steel imports had increased in "such increased quantities" as to permit safeguards; the causal link between increased imports and injury; and the lack of "parallelism" between the injury analysis and the remedial measures. $^{39}$

\subsubsection{Unforeseen developments}

The US law has yet to be amended to require that increased imports result from unforeseen developments, and the initial USITC decision in the steel case predictably paid little heed to the issue. But prior to the imposition of the steel safeguard measures in March 2002, the USTR requested additional information from the USITC regarding unforeseen developments, and received a supplemental report on that issue in February. Based, in large part, on this supplemental report, the United States argued before the Panel that four unforeseen developments had contributed to the influx of imports that had injured the US steel industry: the Asian financial crisis; the drop in demand for steel due to the dissolution of the Soviet Union; the unexpected strength of the US demand for steel; and the persistent appreciation of the US dollar. ${ }^{40}$ Among other arguments, the complainants urged that none of these events were "unforeseen," and questioned whether they had resulted in increased imports sufficient to justify safeguards.

In assessing these issues, the Panel began by noting that the parties agreed that "the point in time at which developments should have

39 United States - Definitive Safeguard Measures on Imports of Certain Steel Products, WT/DS248-49, 251-54, 258-59/R (July 2003) (hereafter Panel Rep.).

${ }^{40}$ Id. $\uparrow 10.40$. 
been unforeseen is that of the completion of the Uruguay Round." 41 The Panel allowed that the Asian financial crisis could constitute an unforeseen development "since it took place after the United States last negotiated its tariff concessions on the steel products covered by the investigation." 42 It noted that the same was true of the consequences for the steel market resulting from the dissolution of the Soviet Union, even though that process had begun prior to the end of the Uruguay Round. The ongoing strength of the US economy and the US dollar were harder to regard as unforeseeable, but the Panel concluded that these factors were not viewed by the USITC as unforeseen developments in themselves, but simply circumstances that contributed to the increase in imports that resulted from the developments in Asia and the Soviet Union. Thus, the United States prevailed on the proposition that unforeseen developments had affected the steel market to some degree.

According to the Panel's interpretation of the text of GATT Art. XIX, however, the unforeseen developments must produce increased imports that cause serious injury or threat. It was on this issue that the United States failed to persuade the Panel, in part because the USITC findings of injury were all contained in the original USITC report rather than its supplemental report - at no time prior to its affirmative injury findings did the USITC identify the increased imports that had resulted from the unforeseen developments and analyze their impact on the domestic industry. Such analysis was required, according to the Panel, for every line of steel products (every "industry") in which a safeguard measure was taken. ${ }^{43}$ Instead, the USITC had simply asserted in its supplemental report, after the original injury findings had been made, that unforeseen developments had affected the steel market in a general way - to which the Panel stated, "in light of the complexity of the matter, a more sophisticated and detailed economic analysis was called for." ${ }^{44}$

The Panel's treatment of the unforeseen developments issue might prove helpful in suggesting how to operationalize this requirement in practice, but at the same time underscores that it is a potentially severe hurdle for any nation that seeks to employ safeguard measures. As to the questions posed earlier in this essay - unforeseen by whom? At what point in time? - the Panel suggests that the relevant actors

41 Id. $\uparrow 10.74 . \quad{ }^{42}$ Id. $\uparrow 10.80 . \quad{ }^{43}$ Id. $\uparrow 10.128 .44$ Id. $\uparrow 0.125$. 
are trade negotiators, and that the relevant time is the point when the member seeking to use safeguards "last negotiated its tariff concessions on the ... products covered by the investigation." The end of the Uruguay Round may be taken to have "reset the clock" on this latter issue, as GATT members formally withdrew from their old GATT obligations at the end of the Round and entered a new (WTO) treaty, even if the tariff bindings on many products did not change.

In deciding whether events were "unforeseen" by the negotiators at the relevant time, the focus in the first instance will be on whether the events in question took place before or after the conclusion of the negotiations. One can thus imagine the rules here evolving in a manner that is roughly consistent with the rules in nonviolation cases - a presumption might arise that negotiators foresee the results of events that take place before the conclusion of negotiations, and do not foresee the results of events that take place later. ${ }^{45}$ As tariffs decline to minimal levels and more and more time passes since the last concession, the set of "unforeseen" events will presumably expand and unforeseen developments should become easier to identify.

The Panel's demand for linkage between unforeseen developments and particular import increases, and the further requirement that these imports be linked to serious injury or threat, is a substantially new interpretation of the obligations imposed by GATT Art. XIX(1). The great virtue of requiring such a linkage between unforeseen developments and injury, via the effect of unforeseen developments on import quantities, is that a coherent exogenous variable thereby resurfaces in the analysis - one asks not whether "increased imports" have caused injury in the abstract, but whether particular unforeseen developments have caused injury, via an effect on the relative competitive position of imported and domestic goods. The question that national authorities are asked to answer is once again economically intelligible, as it was at the outset of GATT.

But the new obligations inherent in the Panel's interpretation do pose some substantial analytical challenges. It is hardly clear what sort of "more sophisticated and detailed economic analysis" will suffice. Consider the steel case itself: By the Panel's reasoning, the United States should have ascertained precisely how much US imports had increased, in each of the 27 steel "industries," as a result of the

45 See Japan - Measures Affecting Consumer Photographic Film and Paper, WT/DS44/R (1998), $\uparrow 10.79$. 
Asian financial crisis and the drop in demand for steel inside the old Soviet Union. It should then have analyzed whether this increase caused or threatened to cause serious injury to the relevant industry (as well as provided a convincing "non-attribution" analysis, discussed further below). On the surface, such an analysis seems to call for a global general equilibrium model of each segment of the steel market, so that the effect of events in particular overseas markets such as Asia and the former Soviet Union can be simulated with precision. If that sort of analysis is indeed required, the time and expense involved could be enormous. The accuracy of such exercises is also subject to considerable doubt because the results often turn on controversial assumptions. And for many industries, the data necessary to estimate the parameters for such models will be lacking, and modelers would have little choice but to fall back on simulations that rest on seat-of-the-pants guesses about relevant supply and demand elasticities, cross-elasticities of demand, and the like. The potential boon for consulting economists is readily apparent, but one must harbor no illusions that the task of undertaking such analysis is straightforward - if done properly, it is expensive, time-consuming, and inevitably fraught with the potential for serious error. Perhaps a future reviewing Panel would be satisfied with something less daunting (and thus less rigorous and even more error prone), but the question of what will suffice as a "reasoned and adequate explanation" of the linkage between unforeseen developments and injury remains unclear at best.

The problem of "non-attribution" might also appear to become more tractable under the Panel's interpretation of "unforeseen developments" - one might say that as long as the unforeseen developments cause increased imports, in turn resulting in injury or threat, then by definition injury has not been "attributed" to any factor other than imports. The task of identifying the other factors to which importrelated injury must not be "attributed," and of assessing their impact, could arguably be put to the side. Conceptual issues still remain, however, as to what is permitted to "count" as an unforeseen development. Imagine, for example, an "unforeseen" shock in the domestic market for inputs into steelmaking that raises the cost of steel production in the United States. The US steelmakers raise their prices to cover costs, and imports flood into the US market to undercut the price increases and market shares of domestic firms. Such "increased imports" may surely be said to cause injury (relative to a counterfactual world in which the imports are not permitted to increase), and to result 
from the unforeseen developments in the domestic input market. But are safeguard measures appropriate when the root cause of injury is a shock in the domestic economy? Or would safeguards to remedy such injury be impermissible because the injury caused by the domestic shock is wrongly "attributed" to imports? Nothing in the WTO decisions thus far afford much help with such matters, an issue about which we will say more below in connection with the "non-attribution" problem.

\subsubsection{Increased imports and the baseline question}

Taking its cue from earlier Appellate Body decisions, the Panel held "that the use of the present tense in the verb phrase 'is being imported' in both Art. 2.1 of the Agreement of Safeguards and Art. XIX:(1)(A) of the GATT 1994 indicate[d] that it [was] necessary for the competent authorities to examine recent imports and that the increase in imports [had been] 'recent.' "46 Further, "the emergency nature of safeguard measures call[ed] for an assessment of whether imports increased suddenly so that the situation became one of emergency." 47 And finally the Panel stated that, given its conclusion that "the competent authority [had to] have determined that imports increased suddenly and recently," it would "generally focus its analysis on the situation of imports in the more recent period that had preceded the end of the period of investigation." 48

The Panel then proceeded to examine the data on import trends for each of the ten product categories covered by the challenged measures. In most instances, the Panel generated a graph representing the import volume and market share data over the five-year period of investigation employed by the USITC. Because the Panel's focus was on the "more recent period that [had] preceded the end of the period of investigation," the graph for each product category says much about how the Panel came out in each case. We produce four of the graphs (Figures 1-4) for purposes of illustration:

For both hot-rolled bar (Figure 1) and stainless steel rod (Figure 2), the Panel found that the USITC report did not contain a "reasoned and adequate" explanation of why imports had increased. Regarding hotrolled bar, the Panel focused on the USITC's "failure to [have]

\footnotetext{
46 Panel Rep. $\mid 10.159 . \quad{ }^{47}$ Id. $\uparrow 10.166 .{ }^{48}$ Id. $\uparrow 10.175$.
} 


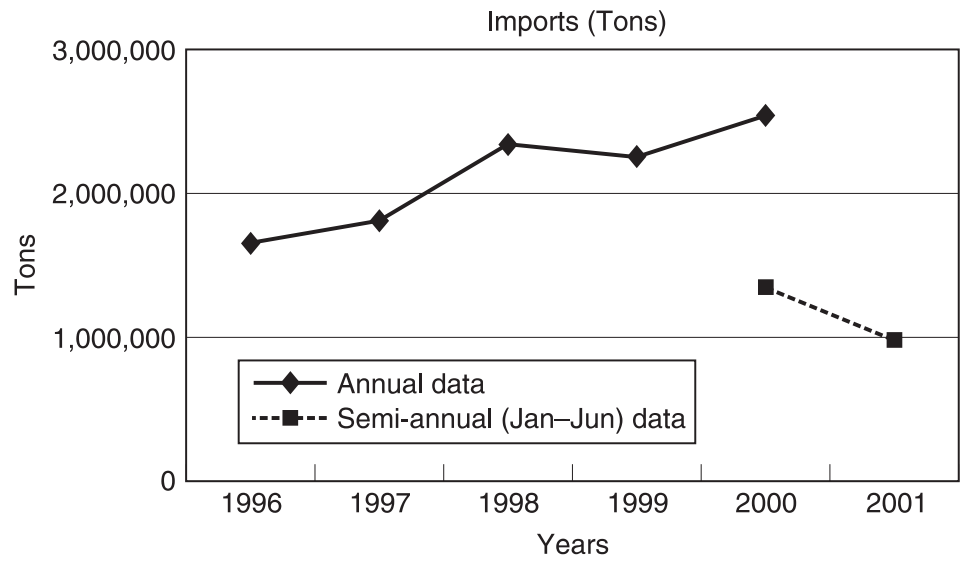

Figure 1 Hot-rolled bar

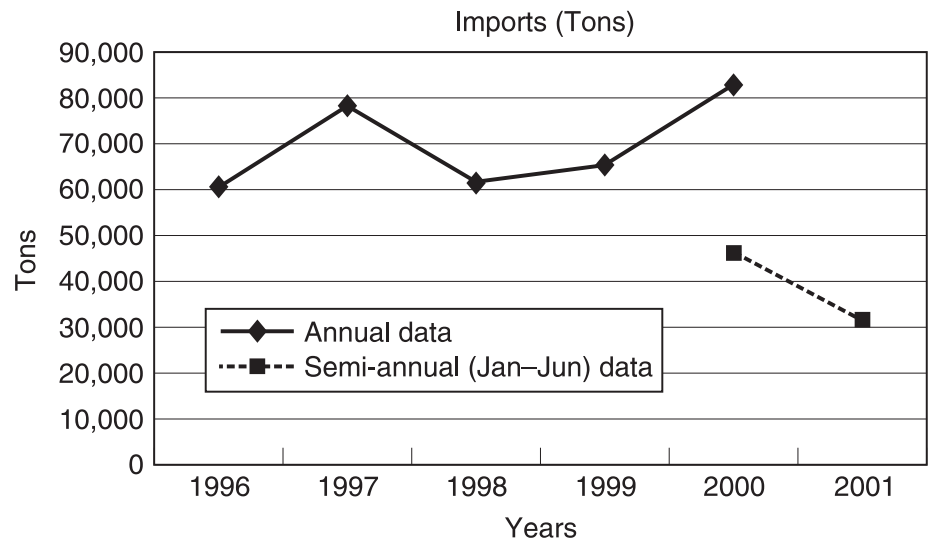

Figure 2 Stainless steel rod

account[ed] for the most recent data from interim 2001..." The Panel stated:

The decrease from interim 2000 (1.34 million tons) to interim 2001 (952,392 tons) represented a decrease by $28.9 \%$, whereas the increase in the year-to-year period before (1999 to 2000) that was characterized as "rapid and dramatic" was merely $11.9 \%$. In light of this decrease in the most recent period, the Panel does not believe that the trend of imports from 1996 to 2000 (an increase by 52.5\%) is sufficient to provide a basis 
for a finding that, at the moment of the determination, hot-rolled bar "is being imported in such increased quantities." 49

The analysis was similar in many respects for stainless steel rod:

The USITC relied on the increase occurring between 1996 and 2000, with the largest increase from 1999 to 2000 (25\%). The decline between interim 2000 and interim 2001 was acknowledged, but the USITC did not give an explanation why it nevertheless found that there was an increase of imports in absolute numbers. This failure is particularly serious since this decrease (by 31.3\%) was sharper than the preceding increase, and, as a matter of proportion, offset the increase of the two preceding years. ${ }^{50}$

For rebar (Figure 3), by contrast, the Panel accepted the USITC finding of increased imports: "In light of the tripling of imports, the decrease over the last 18 months is not significant enough in order to stand in the way of a conclusion that rebar 'is being imported in such increased quantities. " "51

Likewise, as to stainless steel bar (Figure 4), the Panel found:

[I]n the light of the significant increase from 1999 to 2000 (19.3 percentage points), the decline by 3.3 percentage points from interim 2000 to interim 2001 is, contrary to what the European Communities has

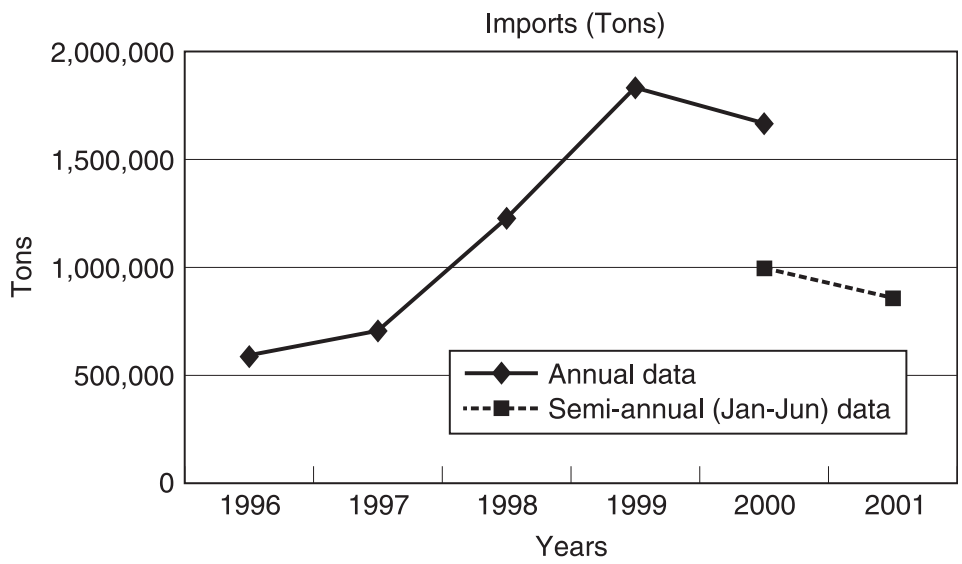

Figure 3 Rebar

49 Id. $\uparrow 10.205 .{ }^{50}$ Id. $\uparrow 10.267 .{ }^{51}$ Id. $\uparrow 10.225$. 


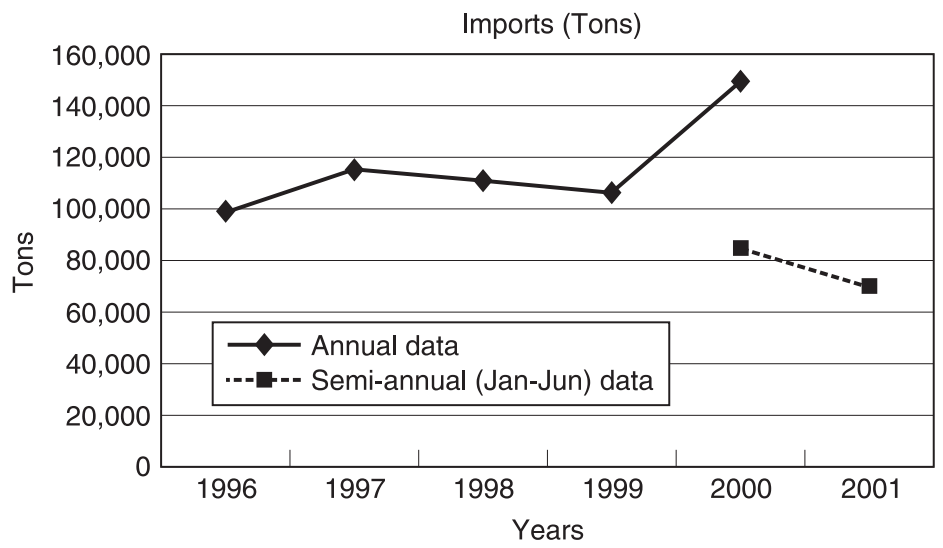

Figure 4 Stainless steel bar

stated, insignificant. It simultaneously does not detract from a finding that imports, relative to domestic production, remain at high levels so that stainless steel bar "is being imported in (such) increased quantities." 52

For two product categories, tin mill products and stainless steel wire, the Panel ruled that the United States failed to demonstrate the presence of increased imports because it had relied on the separate opinions of the USITC Commissioners who had defined the relevant "industries" in different ways. For example, some treated "tin mill products" as a separate industry, while another included tin mill products in a broader industry. The Panel was of the view that the separate findings reached in such a fashion could not collectively constitute a "reasoned and adequate" explanation for the finding of increased imports.

In sum, the Panel's reasoning generally focused on two issues: whether imports had risen substantially over the entire period of investigation (the five-year period ordinarily used by the USITC as its baseline), and whether any recent downtrend in imports had undercut the finding of an overall increase. Implicitly, recent trends carried more weight than the five-year trend, but a modest recent decline in imports

52 Id. $\uparrow 10.254$. 
would not prevent a finding of increased imports if the five-year trend was more dramatically upward.

The Panel's approach is at least somewhat puzzling, for a couple of reasons. First, having held earlier that the United States should have linked import increases to the Asian financial crisis and the dissolution of the Soviet Union, one might have expected the Panel to suggest that the timing of those events defined the baseline for measuring the increase in imports. Instead, as under longstanding US practice, the Panel (and the complainants) seemed to have accepted that the arbitrary five-year baseline was permissible in principle: "The complainants do not challenge the choice of a five-year period of investigation per se. Complainants rather disagree with the fact that, generally, the USITC did not focus sufficiently on the situation of imports in the latest part of the period of investigation." ${ }^{53}$ Second, had the United States in fact linked an increase in imports to unforeseen developments such as the Asian financial crisis and the dissolution of the Soviet Union, and had it shown that the extra imports resulting from these developments were sufficient to cause serious injury, would that not have been enough to establish a basis for safeguard measures? Why did the United States need additionally to show a sudden, sharp and significant increase in total imports? Should the right to safeguard measures have been eliminated, for example, if the effects of the unforeseen developments, working through increased imports, had been reinforced by a slowdown in the US demand, which might have caused additional injury but served to temper the growth in import volume?

The great emphasis on the most recent year or months of data is peculiar in another respect. The time series for imports of any good may exhibit significant volatility for a variety of reasons, and the notion that WTO members would wish to condition the right to use safeguards heavily on the most recent import fluctuations, which may be quite unpredictable when an investigation is initiated, seems odd even if it has some arguable textual basis. The preamble to the Agreement on Safeguards emphasizes the importance of "structural adjustment," much as the US law has long set forth the alternative goals of promoting industrial competitiveness or facilitating an orderly industrial contraction. ${ }^{54}$ If these stated goals are to be taken seriously, they concern

\footnotetext{
53 Id. $\uparrow 10.160 . \quad 54$ See 19 U.S.C. $\S 2251(b)$.
} 
measures to address long-term structural trends. Likewise, Art. 7 of the Safeguards Agreement provides that safeguard measures may be imposed for four years, with the possibility of an extension to eight years. The potential duration of the measures is also suggestive of the notion that they address long-term trends in industrial competitiveness. If this is right, why should the opportunity to utilize safeguard measures turn critically on recent import fluctuations rather than long-term import trends? One wonders whether the Panel here, and the Appellate Body generally, has turned the matter completely on its head.

\subsubsection{Causation and the "non-attribution" problem}

The Panel found fault with the USITC analysis of causation for nine of the ten "industries" covered by the US safeguard measures. In each instance, it held that the USITC had failed to demonstrate a causal link between increased imports and injury, that it had failed to ensure that injury caused by other factors was not "attributed" to imports, or both.

\subsubsection{Demonstrating the causal link to imports Again taking} its cue from prior decisions, the Panel suggested that a causal linkage between increased imports and injury might be established in one of two ways: through a "coincidence" analysis, or through an analysis of the conditions of competition. In the words of the Panel, a coincidence analysis examines the "temporal relationship between the movements in imports and the movements in injury factors." 55 Such coincidence is "normally" evident "if causation is present," 56 although the suggestion that a temporal lag may exist between import increases and injury "may have merit in certain cases." 57 Where a clear coincidence exists, "no further analysis is required of the competent authority," save for a careful non-attribution analysis. ${ }^{58}$ Where coincidence is lacking or an analysis of coincidence has not been undertaken, the competent authority must explain its absence and must show causation convincingly through other means.

According to the Panel, an analysis of the conditions of competition requires the competent authority to consider the factors enumerated

55 Panel Rep. $\uparrow 10.299 . \quad{ }^{56}$ Id. $\$ 10.300 .{ }^{57}$ Id. $\uparrow 10.310 . \quad{ }^{58}$ Id. $\uparrow 10.307$. 
in Art. 4.2(a) of the Safeguards Agreement: changes in import volume, import market share, domestic sales, production, productivity, capacity utilization, profits and losses, and employment. Other unenumerated factors may also be relevant. ${ }^{59}$ In the Panel's view:

$[\mathrm{P}]$ rice $\ldots$ is an important, if not the most important, factor in analysing the conditions of competition in a particular market ... we consider that relative price trends as between imports and domestic products will often be a good indicator of whether injury is being transmitted to the domestic industry ... given that price changes have an immediate effect on profitability, all other things being equal. ${ }^{60}$

Against this backdrop, the Panel proceeded to consider the analysis of the USITC as to each of the challenged measures. In the important category of certain carbon flat-rolled steel (CCFRS), for example, it found:

[T] here was no coincidence between, on the one hand, import trends and the situation of the domestic industry of CCFRS, as reflected in data for production, net commercial sales, productivity and capacity utilization of the domestic CCFRS ... There was [also] a lack of coincidence between import trends and declines in domestic operating margin ... We did discern coincidence, albeit lagged, between increased imports, on the one hand, and employment, on the other hand ... Having taken into consideration all of the foregoing, in the Panel's view, overall, coincidence did not exist. ${ }^{61} \ldots$ Given a lack of coincidence between import trends and the injury factors, it was for USITC to provide a compelling explanation as to why a causal link was considered, nevertheless, to exist. ${ }^{62}$

The USITC's analysis of the conditions of competition for CCFRS was then found deficient as well. The Panel first suggested that the product category might be too broad for such an analysis to be undertaken at all in convincing fashion. Further, according to the Panel, the USITC had apparently relied heavily on evidence of import underselling and downward price trends for both imports and domestic products for two sub-products in the CCFRS category, without explaining "why pricing data for the other three items that constituted CCFRS [had] [not] been specifically considered." And, "while some of the domestically produced constituent items [had been] undersold
59 Id. $§ 10.318$.
60 Id. $\uparrow 10.320$.
61 Id. $₫ 10.374-75$.
62 Id. 10.376. 
by the import counterparts at particular points during the period of investigation, this [had] not necessarily [been] the case for the entire period of investigation." ${ }^{\prime 63}$ Thus, the Panel concluded, the conditions of competition analysis failed to support the existence of a causal link between increased imports and injury.

As to other product lines, the Panel found the USITC's analysis more convincing. For fittings, flanges, and tool joints (FFTJ), the Panel examined the relation between imports and indicators of injury, and noted that "clear coincidence exist[ed] between the upward trend in imports and the downward trend in the injury factors, except for productivity." Because the USITC report had not analyzed this coincidence in detail, however, the Panel also found that a conditionsof-competition analysis was required to support the USITC's finding of a causal link. ${ }^{64}$ In that regard, the Panel reviewed data assembled by the USITC showing that imported products had significantly undersold domestic products during the period of investigation, and on that basis concluded that the conditions-of-competition analysis supported the existence of a causal link.

In the case of hot-rolled bar, the Panel noted that the USITC had not undertaken a coincidence analysis. But as part of its analysis of the conditions-of-competition, the USITC had assembled data on market penetration by imports along with import and domestic prices. The data were presented in the following graph (Figure 5). Based on these data, the Panel concurred that a causal link was present " $[t]$ he USITC explained that domestic prices declined in an effort to mitigate the erosion of market share ... On the basis of the foregoing, overall, we find that the USITC's conditions of competition analysis was compelling." 65

It would be unfair to fault the Panel for following the analytic lead of the Appellate Body and the USITC, but in doing so it followed them to the land of economic gibberish. The Panel insisted that the linchpin in the search for causation was a search for coincidence. The irony of that phrasing is glaring - the Random House English dictionary defines "coincidence" as "a striking occurrence of two or more events at one time apparently by mere chance." The most elementary statistics class teaches that correlation is not causation, and the problem is not ameliorated by relabeling correlation as coincidence.

\footnotetext{
${ }^{63}$ Id. $\uparrow 10.379 . \quad{ }^{64}$ Id. $\uparrow 10.516 . \quad{ }^{65}$ Id. $\uparrow 10.429-30$.
} 
UNITED STATES - SAFEGUARD MEASURES ON STEEL PRODUCTS 175 Imports vs. imports unit values and domestic unit values

(Tons and \$/ton)

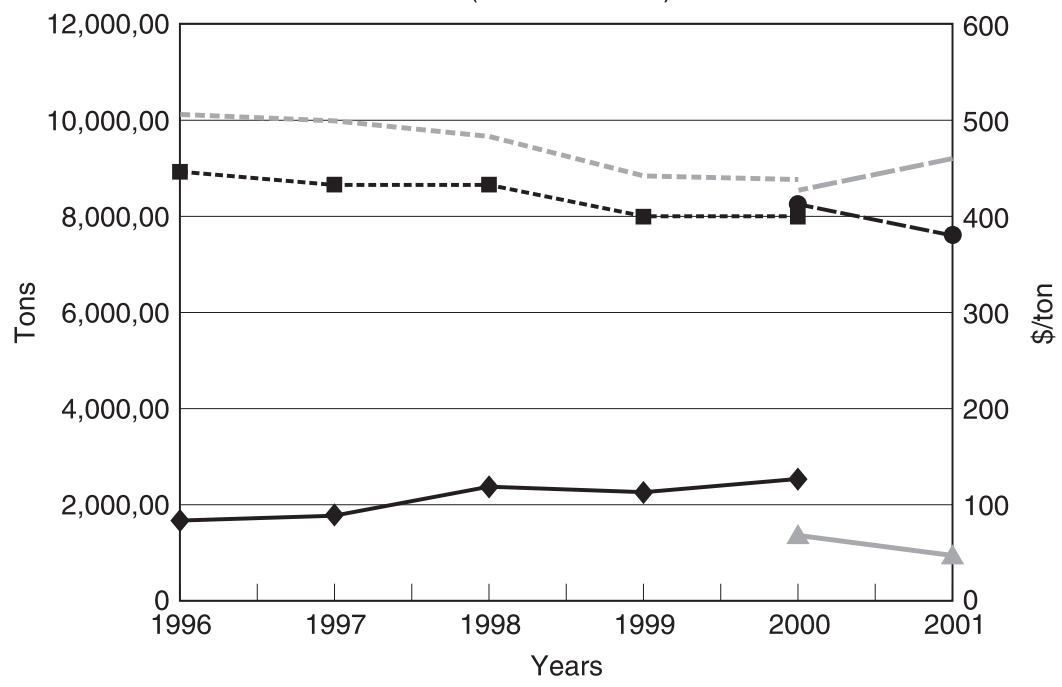

\begin{tabular}{|ll|}
\hline- Imports & - Imports (semi-annual) \\
---- Domestic unit values & $=--=$ Imports unit values \\
--- Domestic unit values (semi-annual) & --- Imports unit values (semi-annual) \\
\hline
\end{tabular}

Figure 5 Hot-rolled bar

Further, as explained earlier, the problem is actually much more fundamental. It is not disreputable to examine correlation as an aid to an exploration of causation with appropriate caveats. But one can only do so when one variable is a logical candidate for the cause of the other. Import quantities do not cause anything - they are simultaneously determined along with prices, domestic output, domestic employment, and so on. It makes no more sense to say that increased imports caused a decline in domestic production, for example, than to say the exact opposite.

The Panel's analysis also involves internal inconsistency. On the one hand, it would require the complainant to identify "unforeseen developments" that are linked to increased imports which in turn have caused serious injury or threat. But on the other hand, it would prescribe a separate causation analysis in which the unforeseen developments play no role. If the Panel's requirements for establishing the existence of unforeseen developments have been met - namely, that 
the domestic industry experienced exogenous shocks that caused import volume to rise and conditions to deteriorate - must not the requirements for causality have been met as well? What additional information can the examination of coincidence provide?

The "conditions of competition" analysis that serves as an alternative to coincidence analysis is no more comforting. To the extent that the Panel, like the USITC, finds evidence of import "underselling" to be persuasive evidence of causation, an economist would respond that persistent underselling by imports is simply an evidence that they are of lower perceived quality for some reason. It says nothing about a causal link between anything and anything else. Likewise, to the degree that a high degree of correlation exists between the price series for imported and domestic goods, that fact is some evidence that the goods are reasonably close substitutes in consumption. Again, no inference of "causation" is supported, as indeed there is no intelligible causal variable under examination.

To be sure, cases will arise in which "coincidence" is relatively stronger or weaker. Cases will arise in which imported goods undersell domestic goods, and many cases will arise in which import and domestic price trends are highly correlated. It will thus be possible for importing nations to demonstrate "causation" with some regularity using the tests that the Panel applies. But if any relationship exists between that set of cases, and the set of cases in which safeguard measures are appropriate on some principled basis, it will arise only by "coincidence."

3.1.3.2 The non-attribution problem Following the lead of the Appellate Body, the Panel made clear that the presence of a "causal link" between imports and injury, as established above, was not enough to satisfy the requirements of the Safeguards Agreement. If other factors also contributed to injury, the "competent authorities [needed to] separate and distinguish the injurious effect of the increased imports from the injurious effects of the other factors."

This exercise is required even though imports need not be solely responsible for injury, but must merely have contributed to it. A proper non-attribution analysis also determines the permissible scope of the safeguard remedy - the Appellate Body ruled in

66 Id. 10.329. 
United States - Line Pipe that safeguard measures may only remedy the injury attributable to increased imports, not that attributable to other factors. ${ }^{67}$

For a number of product lines, the Panel found the USITC's nonattribution analysis to be lacking. The Panel's approach, as in previous cases, was simply to accept at face value the "other factors" put forth by the respondents at the USITC, with no discussion as to how or why they were appropriate or inappropriate. The Panel then checked to see whether the USITC had confidently distinguished the injury attributable to the factor in question, and ensured that such injury was not attributed to imports.

We offer one illustrative example of the analysis: in the case of hot-rolled bar, as noted above, the Panel accepted the USITC's analysis of the conditions of competition as a basis for finding a causal link between increased imports and injury. But the respondents argued before the USITC that injury was caused, inter alia, by increased input costs for domestic producers, what the Panel termed increases in the costs of goods sold (COGS). The USITC acknowledged that COGS had risen during part of the period of investigation, but argued that import competition had suppressed prices and prevented domestic firms from recouping their higher costs. On that basis, the USITC concluded that imports were the more important cause of injury. The Panel evidently considered this analysis too cursory, and thus falling short of a "reasoned and adequate" explanation. The Panel hinted, however, that if the USITC had gone further in its analysis, it might have been able to defend its conclusion. In particular, the Panel noted that there was a general lack of "coincidence" between changes in COGS and operating margins for domestic producers. Had changes in COGS "played a significant role in the situation of the domestic industry," the Panel reasoned, "one would have expected operating margins to increase while COGS was decreasing." 68

The Panel's discussion of the non-attribution requirement suffers from the same logical flaws as the treatment of the issue in prior cases. Its analysis of the COGS factor for hot-rolled bar illustrates the fundamental problem. An increase in input costs for domestic firms will lead them to institute price increases if they can. But, as may have been the case in the hot-rolled bar market, import competition

\footnotetext{
67 Id. $\uparrow 10.338 . \quad{ }^{68}$ Id. $\uparrow 10.440$.
} 
may prevent such price increases. The price increases that are attempted by domestic firms, caused by rising input prices, may thus be the cause of greater import volumes, which restrain price increases and leave domestic firms in a weakened financial situation.

The Panel insists, however, that the injury attributed to rising COGS must be distinguished from the injury attributed to imports. As the above discussion makes clear, this task is logically impossible. If the imports themselves result from increases in COGS, how can the effects of the two possibly be distinguished? Putting it differently, the causal variable in this scenario is an increase in domestic input costs. The result is both an increase in imports, and a weakened financial situation for domestic firms. For the same reason, the proposition that a permissible safeguard measure can address the injury caused by increased imports, but not the injury caused by rising COGS, is also fundamentally incoherent.

The Panel's suggestion that one can analyze the importance of COGS by looking at the coincidence between changes in COGS and operating margins is silly. Other things being equal, increases in COGS will surely tend to lower operating margins, but many other factors in the market are variable over time, and the absence of a "coincidence" between changes in COGS and operating margins simply indicates that other things are happening simultaneously - a clear demonstration of why "coincidence" and causation are two different things. Obviously, the presence of other factors varying simultaneously cannot negate the fact that increases in input costs, other things being equal, are disadvantageous for domestic producers.

The ultimate issue here is a simple one - should safeguard measures be permitted when the cause of injury to a domestic industry, and the cause of rising imports, is a shock to the cost structure of domestic firms? There may be good reasons to answer this question yes or no, but the analysis of the Panel merely masks and confuses it.

\subsubsection{Parallelism}

The "parallelism" requirement stems from Argentina - Footwear. The Appellate Body there held that a correspondence must exist between the imports included in the analysis that led to the injury determination, and the imports covered by the safeguard measure. ${ }^{69}$

${ }^{69}$ Id. $\uparrow 10.590-91$. 
Thus, for example, if imports from Canada were part of the data on which the injury finding rests, imports from Canada cannot be exempted from any subsequent safeguards remedy.

The legal basis for the parallelism requirement is shaky. Pauwelyn (2004) criticizes the requirement and argues forcefully that the real issue is whether Art. XXIV of GATT, pertaining to the formation of customs unions and free trade areas, either requires or permits Members of such entities to exempt imports from other Members from safeguard measures. This question thus far has no clear answer.

Whatever its merits, the parallelism requirement is established in the cases, and the United States undertook to argue that it had complied. The original USITC determination had aggregated imports from all sources, however, while the eventual safeguard measures had largely excluded imports from NAFTA countries, Israel, and Jordan. The USITC was asked to revise its analysis to exclude these imports in its supplemental report to USTR. It did so, and reached the same conclusions for each industry.

The Panel took issue with the analysis for several reasons. In several instances, the USITC had not made clear that it had properly excluded imports from Israel and Jordan in its revised analysis. The USITC also failed to explain to the Panel's satisfaction why its findings had remained the same despite the fact that a smaller quantity of imports had been involved after the parallelism adjustments. In addition, the Panel held that the USITC was obliged to repeat its non-attribution analysis based on the revised import totals, and that it had failed to do so in the supplemental report.

In the interest of parallelism, therefore, the Panel would have the USITC revise its import data, and thereafter undertake the same conceptually-flawed analyses of coincidence, conditions of competition, and non-attribution. The excluded imports would become an "other factor" to which injury from the included imports could not be attributed. But such exercises are no more valuable with the revised data than with the original. Until a logically sound approach to the question of causation emerges, the requirement of parallelism is just a sideshow.

It is also somewhat peculiar that neither the Panel nor the prior pertinent decisions draw any connection between the parallelism issue and the unforeseen developments issue. If the United States is obliged by Art. XIX to draw a connection between injury and developments in Asia and the former Soviet Union, is it not possible that such injury 
was transmitted through an effect on imports from particular sources, rather than an effect on all imports or on world prices? Does the answer to that question have any implications for the permissible scope of the safeguard remedy, or for the possible exclusion of imports from particular sources?

\subsection{The Appellate Body decision}

The Appellate Body affirmed the Panel in most pertinent respects, or exercised judicial economy to avoid reaching the issues raised. ${ }^{70}$ We can thus address its decision with considerable brevity.

\subsubsection{Unforeseen developments}

Much of the US appeal on this issue consisted of a challenge to the "standard of review" employed by the Panel - a requirement that the US competent authorities provide a "reasoned and adequate" explanation for their findings. The Appellate Body essentially affirmed the standard employed by the Panel, and we have no quarrel with the general principle that national authorities should set forth findings with enough clarity and logical reasoning for reviewing Panels to be able to assess them.

The Appellate Body also concurred with the Panel that a Member proposing to invoke safeguards must demonstrate that unforeseen developments have led to increased imports for each "industry" covered by a safeguard measure. ${ }^{71}$ Here too it affirmed the finding that the USITC had failed to make such a showing with a "reasoned and adequate" explanation. ${ }^{72}$ We have no quarrel with this principle either as a general matter. The treaty text requires the preconditions for safeguards to be met for any "product" covered by a safeguard measure. When, as in the steel case, national authorities determine that a number of different "products" are involved and proceed to define a number of separate "industries" to investigate, it is appropriate to require that the preconditions for safeguard measures be met in each industry.

But the Appellate Body opinion does not address the deeper issues raised by the unforeseen developments requirement. It expressly states that it offers no ruling on the question whether the developments

70 United States - Definitive Safeguard Measures on Imports of Certain Steel Products, WT/DS248-49, 251-54, 258-59/AB/R (November, 2003) (hereafter App. Body Rep.).

${ }^{71}$ Id. $\uparrow 319 .{ }^{72}$ Id. $\uparrow 326$. 
identified by the United States - the Asian financial crisis, the dissolution of the Soviet Union, and so on - actually constitute "unforeseen developments" as a legal matter. ${ }^{73}$ It thus offers no guidance on how one determines what is "unforeseen," or what is permitted to "count" as an unforeseen development. Most importantly, it does not address the ultimate issue, raised implicitly by the Panel's analysis, as to whether national authorities must convincingly link all of the "serious injury" caused by "increased imports" to the underlying "unforeseen developments." If indeed they must, then the requisite analysis becomes somewhat better grounded in a coherent economic theory on the one hand, but the task of producing a "reasoned and adequate" justification for a safeguard measure becomes all the more daunting on the other.

\subsubsection{Increased imports}

Here, the Appellate Body reaffirmed the principle set forth in Argentina - Footwear that a mere increase in imports is not enough to satisfy the requirement of "such increased quantities" as to cause injury. It quoted with approval its prior reference to a requirement that "the increase in imports [] have been recent enough, sudden enough, sharp enough, and significant enough, both quantitatively and qualitatively, to cause or threaten to cause 'serious injury," "74 and found that the Panel had interpreted this standard correctly. In so doing, the Appellate Body did nothing in our view to clarify the practical application of the standard. Likewise, its decision does little to explain the logic behind the standard - why do the consequences of "unforeseen developments" not unfold slowly at times, so that the resulting increase in imports is not particularly sudden or sharp? And, at the risk of seeming repetitive, what sense does it make to fret about the time period over which increased imports may or may not have caused injury, when the law offers no coherent theory of how imports cause anything? On these fundamental conceptual issues relating to the increased imports requirement, the marginal contribution of the opinion is nil.

Regarding the Panel's findings with respect to specific product categories, the Appellate Body for the most part affirmed, to the extent that the Panel's findings were appealed by the United States.

\footnotetext{
73 Id. $\mid 269 . \quad{ }^{74}$ Id. $\uparrow 345-46$.
} 
We critiqued the Panel's analysis at some length above on these issues, and will not repeat the discussion here.

The Appellate Body did reverse the Panel's findings with regard to tin mill products and stainless steel wire. Contrary to the Panel's conclusion, the Appellate Body held that the findings of different Commissioners, who had defined the industries in varying ways, could in principle suffice as a "reasoned and adequate" explanation for a finding of increased imports. ${ }^{75}$ According to the Appellate Body, nothing in the treaty text precluded an aggregation of judgments in this fashion, nor was it logically inconceivable that analyses based on different conceptions of the "industry" might nevertheless justify a finding of increased imports. Having reversed the Panel on this point, however, the Appellate Body found it unnecessary to complete the Panel's analysis because it held the safeguard measures for tin mill products and stainless steel wire to be illegal on other grounds. ${ }^{76}$ The reversal of the Panel here may be of some modest comfort to the United States, with its history of ITC Commissioners who often arrive at different definitions of the relevant "industry" in safeguards proceedings, but seems to be of modest conceptual importance.

In sum, as with its treatment of the unforeseen developments requirement, the Appellate Body decision adds nothing of significance to its previous decisions beyond tacit approval of the analysis conducted by the Panel on several of the product categories. Our thoughts on that analysis are set forth above.

\subsubsection{Parallelism}

The Appellate Body agreed with the Panel that the USITC had not shown that it had properly excluded imports from Canada, Mexico, Israel, and Jordan in reaching its findings. It emphasized especially that the USITC had not considered the excluded imports as an "other factor" in a proper non-attribution analysis. ${ }^{77}$ We have no quarrel with the factual proposition that the USITC's reasoning on this front was murky, although the task of fixing the problem remains confounded by the absence of any coherent way to identify the impact of the relevant set of "increased imports," or to separate the injury caused thereby from injury caused by other factors. Until a conceptual framework

75 Id. $\uparrow 416,429 . \quad 76$ Id. $\uparrow 431 . \quad{ }^{77}$ Id. $\uparrow 4456$. 
for identifying the relevant exogenous variables and assessing their impact is articulated, it is simply not clear how to implement a requirement of parallelism. And in the absence of an intelligible theory as to when safeguard measures are appropriate and when they are not, it is impossible even to say whether a "parallelism" requirement makes sense.

\subsubsection{Causation}

Because its rulings on the unforeseen developments, increased imports, and parallelism issues sufficed for finding that each of the ten challenged measures violated WTO law, the Appellate Body declined to consider the Panel's analysis of the causation issue. It simply referred the parties to its prior rulings for further "guidance," rulings with which we have already taken issue.

In sum, unlike its prior rulings in the safeguards area, the Appellate Body ruling in the steel dispute offers virtually nothing of conceptual importance. To the extent that any important new law was made, it consisted of affirming the reasoning of the Panel on certain key points that have already been discussed extensively above. Nothing in the opinion resolves any of the conundrums raised by prior Appellate Body decisions.

\section{Concluding commentary}

Our review of the steel dispute suggests how difficult it will be for WTO members to use safeguards going forward without a prospect of near-certain defeat when a complaint is brought against them. Members must demonstrate the existence of unanticipated developments, argue persuasively that they were "unforeseen," convincingly trace their impact on increased imports, demonstrate that much of the import surge was sufficiently "recent," convincingly show the relation between the imports and serious injury to an appropriately defined "industry," and convincingly show that "other factors" did not cause the injury attributed to increased imports. And they must accomplish these things in a theoretical vacuum, where neither the treaty text nor the Appellate Body decisions to date offer any clear explanation of what it even means to say that "increased imports" have "caused" or threatened to cause serious injury, how one identifies the "other factors" that might be responsible for injury, and how 
one attributes injury among its various causes. Because it is unclear what the law requires as a conceptual matter, it is exceedingly difficult to comply with it, and one can hardly fault national authorities for their inability to offer a "reasoned and adequate" demonstration of their fidelity to the law.

To be sure, some observers may welcome these developments. For those who believe that safeguard measures are nothing more than wasteful protectionism, insurmountable hurdles to their use will have appeal. But the literature is in fact rather agnostic on the use of safeguards. Bagwell and Staiger $(1990,2002)$ suggest that safeguard measures may be understood as a device for reducing the pressure on nations to cheat on trade agreements, and thus can reduce the danger that the agreements may unravel. Sykes (1991) argues that the opportunity to employ safeguard measures ex post may facilitate more trade concessions ex ante in an environment where negotiators face political uncertainty about the consequences of their trade concessions. And the experience of the GATT suggests that if safeguard measures become unavailable, nations may return to arrangements such as voluntary export restraints that are even worse from the ex post standpoint because no standard restricts their use or limits their duration - the political pressures to protect troubled industries through trade policy will remain regardless of the state of the law, as will their potential to cause mischief.

It is thus plausible that safeguard measures have a constructive role to play in the trading system. If they are to play that role effectively going forward, however, the law must evolve in a way that makes clear to WTO members what circumstances are appropriate for safeguards, and how to go about demonstrating the existence of those circumstances. For the reasons given above, the treaty text is woefully deficient in this regard, and the decisions of the Appellate Body have only compounded the problem.

One way or another, what is needed is a fresh start. We can imagine it coming in two ways. First, the Appellate Body might change course dramatically, and initiate a "common law" evolution toward coherent standards for the use of safeguards, much as the US courts have done in fleshing out the vague and imprecise standards of the US antitrust laws. To do so, however, the Appellate Body would have to abandon its insistence on grounding every principle in treaty text, in favor of ascertaining the "object and purpose" of the Safeguards Agreement from other sources, perhaps even by some 
direct appeal to economic theory. Such a process would represent a major departure from the Appellate Body's usual approach to cases, however, and many might question the legitimacy of such a departure. Alternatively, the WTO membership might simply renegotiate the Agreement on Safeguards, with an eye toward resolving the fundamental issues that we have identified (and no doubt some that we have not). At this writing, neither possibility appears terribly likely in the foreseeable future.

Whatever the near-term likelihood of legal reform, the economic literature does offer some ideas on possible directions for change. A number of economic scholars advocate an interpretation of the legal prerequisites for safeguards that melds easily with basic price theory, an approach that actually surfaced briefly in the reasoning of a few USITC Commissioners. ${ }^{78}$ Grossman (1986), Kelly (1988), and Irwin (2003) would divide the potential causes of injury into three groups: forces that cause shifts in the domestic supply schedule; forces that cause shifts in the domestic demand schedule; and forces that cause shifts in the import supply schedule. Any harm to the domestic industry that can be attributed to shifts in the import supply curve will be deemed to result from "increased imports;" any harm attributable to rising domestic costs that shift the domestic supply schedule will be deemed to result from causes other than increased imports. Likewise, harm due to shifts in domestic demand will be attributed to causes other than imports, unless the shift in demand is due to a price reduction on imperfectly substitutable imports. This approach also has the great virtue of economic coherence, shifting the inquiry to ask whether changing conditions of import supply, rather than increased quantities of imports, are causally responsible for injury. It does not, however, address the problem of what counts as an "unforeseen development," or whether such a requirement is desirable and appropriate. And we do not pretend that it would always be easy to implement as a practical matter. The data requirements for confident estimation of the pertinent supply and demand relationships may often be lacking, and the task of identifying and specifying those relationships can be controversial.

Critics may also argue that the import supply approach is not the only coherent way to implement a safeguards system, and may

${ }^{78}$ See US International Trade Commission, Wood Shakes and Shingles, Inv. No. TA-201-56, Pub. No. 1826 (1986) (views of Commissioners Liebeler and Brunsdale). 
preclude safeguard measures in cases where WTO members might agree they ought to be permissible. The old GATT Hatter's Fur case noted above is instructive in this regard. The US position in that case was, that a decline in domestic demand for the types of hats produced by domestic firms was the "unforeseen development" that resulted in an import surge and that justified safeguards action. The working party appeared to accept this theory, at least in principle, while quibbling as to whether the facts supported it.

Sykes (2003) suggests a slightly different set of principles. Noting that the original structure of Art. XIX was aimed at protecting against the "unforeseen" consequences of trade concessions that might produce import surges, he suggests that safeguards may be appropriate when unanticipated shocks lead exporters to enjoy unanticipated prosperity while import-competing firms simultaneously suffer severe and unexpected declines. Such an approach could permit a safeguard measure on the facts of the Hatter's Fur case, for example. This approach too leaves many details to be worked out, most especially the issue of how to determine whether shocks are unanticipated, and is no more than an initial step toward articulating the role of safeguards in the system.

Our goal here is not to opine definitively on the proper logic of safeguards. That task, of course, is a matter for the WTO membership. We simply suggest that economically oriented scholars may offer some useful ideas for the reform of safeguards law, and that they can at least help to suggest what sort of framework will stand the test of logical coherence. Current WTO jurisprudence flunks that test miserably, and without reform will continue to present insuperable obstacles to the use of safeguard measures. We are unsure about the systemic consequences of this state of affairs, but are by no means confident that the consequences are benign.

\section{References}

Bagwell, K. and Staiger, R. W. (1990). A Theory of Managed Trade, American Economic Review, 80: 779-795.

Bagwell, K. and Staiger, R. W. (2002). The Economics of the World Trading System (Cambridge, MA: The MIT Press).

Grossman, G. M. (1986). Imports as a Cause of Injury: The Case of the US Steel Industry, Journal of International Economics, 20: 201-222 
Grossman, G. M. and Mavroidis, P. C. (2005). United States - Definitive Safeguard Measures on Imports of Circular Welded Carbon Quality Line Pipe from Korea. In H. Horn and P. C. Mavroidis (eds.), The WTO Case Law of 2002. American Law Institute Reporters Series (Cambridge, UK: Cambridge University Press).

Horn, H. and Mavroidis, P. C. (2003). United States - Safeguard Measures on Imports of Fresh, Chilled or Frozen Lamb Meat from New Zealand and Australia: What Should be Required of a Safeguard Investigation?. In H. Horn and P. C. Mavroidis (eds.), The WTO Case Law of 2001. American Law Institute Reporters Series (Cambridge UK: Cambridge University Press).

Kelly, K. (1988). The Analysis of Causality in Escape Clause Cases, Journal of Industrial Economics, 37: 187-207.

Irwin, D. (2003). Causing Problems? The WTO Review of Causation and Injury Attribution in US Section 201 Cases, World Trade Review, 2: 297-325.

McGovern, E. (1986). International Trade Regulation, 2nd edn. (London: Gobefield).

Pauwelyn, J. (2004). The Puzzle of WTO Safeguards and Regional Trade Agreements, Journal of International Economic Law, 7: 109-142

Sykes, A. O. (1991). Protectionism as a 'Safeguard': A Positive Analysis of the GATT 'Escape Clause' with Normative Speculations, University of Chicago Law Review, 58: 255-305.

Sykes, A. O. (2003). The Safeguards Mess: A Critique of Appellate Body Jurisprudence, World Trade Review, 2: 261-295.

Sykes, A. O. (2004). The Persistent Puzzles of Safeguards: Lessons from the Steel Dispute, Journal of International Economic Law, 7: 523-564. 